dini araștırmalar dergisi

Turkish Journal of Religious Studies

cilt / volume: 21 • sayı / issue: 1 • yaz / summer 2021

\title{
İmam Hatip Ortaokulu Öğrencilerinin Okul Motivasyonlarının Çeşitli Değişkenler Açısından İncelenmesi (Erzurum İli Örneği)
}

\author{
An Investigation of the School Motivations of Imam Hatip Middle \\ School Students in Terms of Various Variables (Erzurum province as \\ an example)
}

Metin Çiftçi*

Arş. Gör., Onsekiz Mart Üniversitesi, İlahiyat Fakültesi, Din Eğitimi Anabilim Dalı

Research Assist., Onsekiz Mart University, Faculty of Theology, Department of Religious Education Çanakkale, Turkey

metinciftci@comu.edu.tr | https://orcid.org/0000-0002-8573-7807

*Sorumlu Yazar / Corresponding Author

\section{Eyüp Şimşek}

Prof. Dr., Atatürk Üniversitesi, İlahiyat Fakültesi, Din Eğitimi Anabilim Dalı

Professor, Atatürk University, Faculty of Theology, Department of Religious Education

Erzurum, Turkey

eyupsimsek@atauni.edu.tr | https://orcid.org/0000-0002-4393-7616

Article Type / Makale Tipi

Research Article / Araştırma Makalesi

DOI: $10.33420 /$ marife. 886765
Article Information / Makale Bilgisi

Received / Gelis Tarihi: 26.02.2021

Accepted / Kabul Tarihi: 28.05.2021

Published / Yayın Tarihi: 30.06.2021

Cite as / Atıf: Çiftçi, Metin- Şimşek, Eyüp. “İmam Hatip Ortaokulu Öğrencilerinin Okul Motivasyonlarının Çeşitli Değişkenler Açısından İncelenmesi (Erzurum İli Örneği)”. Marife 21/1 (2021), 279301. https://doi.org/10.33420/marife.886765

Plagiarism /Intihal: This article has been reviewed by at least two referees and scanned via a plagiarism software. / Bu makale, en az iki hakem tarafindan incelendi ve intihal içermediği teyit edildi.

\section{(c) (1) () $\odot$}

Copyright / Telif HakkI: "This article is an open access article distributed under the terms and conditions of the Creative Commons Attribution-NonCommercial-NoDerivatives 4.0 (CC BY-NC-ND 4.0) International License." / "Bu makale Creative Commons Alınt-GayriTicari-Türetilemez 4.0 (CC BY-NCND 4.0) Uluslar arası Lisansı altında lisanslanmıştır."

*Ethical Statement / Etik Beyan: This work prepared from Metin CliFTCII's "School Motivation of Imam-Hatip Middle School Students" titled master's thesis. / Bu çallşma, Metin ÇIFTÇI'nin "İmam Hatip Ortaokulu Öğrencilerinin Okul Motivasyonları" başlıklı yüksek lisans tezinden üretilmiștir. 


\section{İmam Hatip Ortaokulu Öğrencilerinin Okul Motivasyonlarının Çeşitli Değişkenler Açısından İncelenmesi (Erzurum İli Örneği)}

\section{Özet}

Bu araştırma, imam hatip ortaokullarında okuyan öğrencilerin okul motivasyonlarında hangi değișkenlerin farklılașmaya neden olduğunu ortaya koyarak, öğrencilerin okul motivasyonlarının yükseltilmesi ve yüksek olan motivasyonların sürdürülebilmesi için öneriler sunmak amacıyla tasarlanmıştır. Bu amaç doğrultusunda; öğrencinin cinsiyeti, okuduğu sınıf, anne ve baba eğitim durumu, imam hatip ortaokuluna kaydolma nedeni, imam hatip ortaokulu öncesi Kur'an-ı Kerim okumayı bilme durumu ve imam hatip lisesine devam isteği ile ilgili sorularla öğrencilerin profili belirlenmeye çalışılmış; bunların okul motivasyon düzeylerinde farklıllk oluşturup oluşturmadiğı istatiksel olarak analiz edilmiștir. Araștırma, nicel araștırma yöntemlerinden tarama modeli çerçevesinde tasarlanmıştır. Araștırmanın evreni, 2018-2019 eğitim-öğretim yılı bahar yarıyılında, Erzurum ili merkez ilçelerinde bulunan imam hatip ortaokullarında okuyan öğrencilerden oluşmaktadır. Araștırmanın örneklemi tesadüfi örnekleme ile belirlenmiș ve 370'i \%(47,6) erkek, 408'i $(\% 52,4)$ kız olmak üzere toplam 778 ögrenciden olușmuştur. Araştırmada, kişisel bilgi formu ve Kaynak, Özhan, ve Kan (2017) tarafindan geliştirilen okul motivasyonu ölçeği kullanılmıștır. Üç boyuttan oluşan ölçek, ortaokul öğrencilerinin davranışsal, bilişsel ve duyuşsal özellikleri göz önüne alınarak hazırlanmış olup, 14 sorudan oluşan 5'li likert tipi derecelendirme ölçeğidir. Ölçekten alınan puanlar arttıkça, ögrencinin okul motivasyonu düzeyi de artmaktadır. Ölçekten alınabilecek en yüksek puan 70'tir. Ölçekten alınan puanlar arttıkça öğrencinin okul motivasyon düzeyi artmaktadır. Ortaokul ögrencilerinin okul motivasyonuna ilişkin toplam varyansın \%68.665'ini açılamakta olup, ölçeğin doğrulayıcı faktör analizi (DFA) sonuçları; $x^{2} / d f=2.963, C F I=.952, T L I / N N F I=.939$, GFI=.920, AGFI=.883, RMSEA=.076 [\%90 CI: .064 - .087] olarak hesaplanmıştır (Kaynak v.d., 2017). Bu çalışmada ise $x^{2} / d f=4.76, C F I=.826, T L I / N N F I=.993, G F I=.937, A G F I=.910, R M S E A=.070$ [\%90 CI: .062 - .077] olarak hesaplanmıștır ve Wheaton v.d'ne (1977) göre ölçek mevcut yapısal özellikleriyle geçerli bir ölçek olarak değerlendirilebilir. Geliştirici tarafından ölçek maddelerinin tamamı için yapılan testte Cronbach Alfa iç tutarlık katsayısl 84 olduğu görülmektedir. Bu araştırmada maddelerin tamamının Cronbach Alfa iç tutarlık katsayısi .75 olarak hesaplanmıştır.

Araştırma kapsamında elde edilen verilerin analizinde SPSS 20.0 (Statistical Package for Social Sciences) bilgisayar istatistik paket programı kullanılmıştır. Araştırmada iki alt kategoriye sahip Bağımsız Değişkenler için t-Testi (Independent-Samples t-Test) kullanılmıș, ikiden fazla alt kategoriye sahip bağımsız değişkenler için ise, Tek Yönlü Varyans Analizi (One-Way ANOVA) testi uygulanmıştır. ANOVA testi ile yapılan analizler sonucunda, grupların ortalama puanları arasında farklılı tespit edilmişse bu farklılı̆ın hangi gruplardan kaynaklandığını bulabilmek için Levene Testi yapılarak varyansların homojenliğine bakılmıştır. Eşit örneklem sayısı sağlanamadığında ve varyansların homojenliğini gerektirmesi nedeniyle Post Hoc. Bonferroni tercih edilmiștir. Eșit örneklem sayısı gerektirmemesi ve varyansların homojenliği sağlanmadığında ise Games-Howell testi kullanılmıștır.

Elde edilen bulgular analiz edildiğinde; anne ve baba eğitim durumu, imam hatip ortaokulu öncesi Kur'an-ı Kerim okumayı bilme durumu, öğrencilerin okul motivasyonu düzeylerinde farklllık olușturmadığı görülmüștür. Öğrencilerin cinsiyetleri, bulundukları sınıf düzeyi, okula kayıt nedenleri ve imam hatip lisesine devam etme isteği ile okul motivasyonları arasında anlamlı farklılı tespit edilmiștir.

Araștırmanın sonuçları değerlendirildiğinde, imam hatip ortaokullarına yeni başlayan öğrencilerin okul motivasyonlarının yüksek olduğu görülmüştür. Ortaokula yeni başlayan öğrencilerin yüksek olan okul motivasyonlarının ilerleyen yıllarda da yüksek tutulmaya çalışılmalı ve bu konuda öğrencileri motive edici faaliyetler geliştirilmelidir. Eğitim programları öğrencilerin ilgisini çekecek şekilde hazırlanmalı ve öğretmenler, sınıflar ilerledikçe öğrenciler için zor hale gelmesi muhtemel konuları öğrencinin ilgisini her daim canlı tutacak șekilde sunmalıdır. İmam hatip ortaokuluna kendi isteğiyle kayıt yaptıran öğrencilerin okul motivasyonlarının, ailesinin isteğiyle kayıt yaptıran ögrencilerin okul motivasyonlarına göre yüksek olduğu ve istatistiksel olarak anlamlı bir farkllaş̧ma olduğu görülmüstür. Farklılığın azaltılabilmesi için aileler ve öğrenciler okul hakkında bilgilendirilmeli ve ögrencilerin okula kendi istekleriyle kayıt yaptırmaları sağlanmalıdır.

Anahtar Kelimeler: Din Eğitimi, Motivasyon, Okul Motivasyonu, Ortaokul, IHO (İmam Hatip Ortaokulu). 

Terms of Various Variables (Erzurum province as an example)

\section{Summary}

This research was designed to reveal which variables cause differentiation in school motivation of students studying in imam hatip middle schools and to provide suggestions to increase the students' school motivation levels and maintaining their high motivation. In accordance with this purpose; The profile of the students was tried to be determined by questions about the gender of the student, the class he/she attended, the education status of the parents, the reason for enrolling in the imam hatip middle school, whether they knew how to read the Quran before the imam hatip secondary school, and the request to attend the imam hatip high school; Whether these made a difference in school motivation levels was analyzed statistically. The research was designed by scanning model. The population of the study consists of students who studied at imam hatip middle school in the central districts of Erzurum in the spring semester of the 2018-2019 academic year. The sample of the study was determined by random sampling and consisted of a total of 778 students, 370 (47.6\%) of which were boys and 408 (52.4\%) girls. In the study, the personal information form and school motivation scale developed by Kaynak, Özhan, and Kan (2017) to measure the school motivation levels of students studying at secondary school were used. The scale, which consists of three dimensions, was prepared by considering the behavioral, cognitive, and affective characteristics of middle school students, and it is a 5-point Likert-type rating scale consisting of 14 questions. As the scores obtained from the scale increase, the student's level of school motivation also increases. The highest score that can be obtained from the scale is 70 . It explains $68.665 \%$ of the total variance regarding the school motivation of middle school students, and the confirmatory factor analysis (CFA) results of the scale are; $x^{2} / d f$ =2.963, CFI=.952, TLI/NNFI=.939, GFI=.920, AGFI=.883, RMSEA=.076 [\%90 CI: .064 - .087] (Kaynak et al. , 2017). In this study, $x^{2} / d f=4.76, C F I=.826, T L I / N N F I=.993, G F I=.937, A G F I=.910, R M S E A=.070$ [\%90 CI: .062 - .077]. It has been calculated and according to Wheaton et al. (1977), the scale can be evaluated as a valid scale with its existing structural features. In the test conducted by the developer for all scale items, the Cronbach Alpha internal consistency coefficient is .84. In this study, the Cronbach Alpha internal consistency coefficient of all the items was calculated as 75.

SPSS 20.0 (Statistical Package for Social Sciences) computer statistics package program was used in the analysis of the data obtained within the study. In the study, t-Test (Independent-Samples t-Test) was used for Independent Variables with two sub-categories, and the One-Way Analysis of Variance (One-Way ANOVA) test was applied for independent variables with more than two sub-categories. As a result of the analyzes made with the ANOVA test, if a difference was detected between the mean scores of the groups, the Levene test was performed to find out which groups this difference originated from, and the homogeneity of the variances was checked. Hence, the Post Hoc. Bonferroni is preferred. The Games-Howell test was used when it did not require an equal sample size and the variances were not homogenous.

When the results of the study were evaluated, it was seen that the school motivation of the students who just started imam hatip middle schools was high. The high school motivation of the students who have just started middle school should be tried to be kept high in the following years and activities should be developed to motivate students in this regard. Educational programs should be prepared in a way that draws the attention of students, and teachers should present topics that are likely to become difficult for students as the lessons progress, in a way that will keep the student's interest alive at all times. It was observed that the school motivation of the students who enrolled in imam hatip middle school voluntarily was higher than those who enrolled at the request of their families, and there was a statistically significant difference. To reduce the difference, families, and students should be informed about the school and students should be made to enroll in the school voluntarily.

Keywords: Religious Education, Motivation, School Motivation, Middle School, IHO (İmam Hatip Middle School).

\section{Giriș}

Osmanlı'nın son dönemlerine denk gelen, eğitimde ıslah çalışmalarının merkezinde dönemin ana eğitim kurumları olan medreseler yer almıştır. Medreselerin ıslahı düşüncesiyle "geleneksel" ve "modern" eğitimi bir arada verebilmeyi 
amaçlayan, bugünün imam hatip okullarına benzer eğitim programlarına sahip, Daru'l-Hilafeti'l-Aliye Medreseleri ve Medresetü'l-Eimme ve'l Huteba kurulmuştur. Böylece medreselerde verilen geleneksel eğitimin yanında batı tarzı modern eğitim verilmeye başlanmıștır. Bu okullar, cumhuriyete geçişle din hizmetlerinde görevlendirilecek personelin yetiștirilmesi amacıyla varlıklarını imam hatip okulları şeklinde korumuşlardır. Bu okullarda din eğitiminin yanında matematik, fen ve sosyal bilimlerde eğitim verilmektedir. ${ }^{1}$ Bu okulların ilk kademesi olan imam hatip ortaokullarına çocuklarını gönderen aileler, çocuklarının akademik başarılarının yanında dini bilgilere de sahip olmalarını istemektedirler. Bu nedenle zorunlu eğitimin önemli bir kademesi olan ortaokullarda, öğrencilerin profillerinin bilinmesi, eğitim-öğretim programlarının ve ailelerin hedeflediği kazanımlara ulaşmada, okul motivasyonlarını arttırıcı uygulamalar ve etkinlikler sunabilmek için önemli bir hale gelmiştir.

Günümüzde, birçok gelişmiş veya gelişmekte olan ülkede olduğu gibi, ülkemizde de çocuklar, zorunlu bir eğitime tabi tutulmaktadır. Çocuğun ve ebeveynlerinin mevcut eğitim sistemine tabi olma dışında seçenekleri yoktur. Bu durumda böyle bir sistemin amacl, yetenekli bireyi seçmek ve yetiştirmekten ziyade, toplumu oluşturan her bir bireyi eğitmek ve onda var olan yetenekleri geliștirmek olmalıdır. Bu amaca sahip, zorunlu bir eğitim süreci sunan eğitim sistemi, çocuklar için eğitimi çekici ve anlamlı bir hale getirme yolarını bulmak, çocuklarda var olan yetenekleri ortaya çıkartıp geliştirmek mecburiyetindedir. Eğer zorunlu olarak sunulan bu eğitim, öğrencilerin çoğu için çekici, anlamlı ve öğrenilebilir bir şekilde sunulamaz ise telafisi mümkün olmayan bireysel ve toplumsal sorunlara neden olacağı da açık bir şekilde öngörülebilmektedir. Zorunlu eğitimde, okul, eğitimi cazip hale getirmez ise öğrenciler enerjilerini ve potansiyellerini farklı alanlara yönlendirerek okulda ve çevresinde çeteleşme, organize suç işleme, ahlaksızlığı öğrenme, zorbalık gibi toplumda istenmeyen davranışlar sergileyeceklerdir. ${ }^{2}$

Motivasyon, bireyin öğrenme azminin önemli belirleyicilerinden biridir. ${ }^{3}$ Motivasyon, bireyi belirli uyarıcılara karșı belirli tepkiler vermeye zorlamaktadır. Bunun sonucunda bireyde zoraki bir öğrenme meydana gelmektedir. Bu nedenle motivasyon, öğrenme için olmazsa olmaz bir gereklilik olarak karşımıza çıkmaktadır. Yeteri kadar motive edilmemiş öğrencide öğrenme gerçekleşmemektedir, çünkü öğrenmeye hazır değildir. Öğrenciyi uyaracak ve motive edecek önemli sebepler sunulmadıkça, öğrencide öğrenme gerçekleşmeyecektir. Her insan gibi öğrenciler de meraklarını celbeden ilgi duydukları konuları öğrenmeyi seçerler ve bunları kolayca öğrenebilirler. Fakat okullarda sunulan bilgilerin hepsi, öğrencilerin ilgi duydukları ve merak ettikleri konulardan oluşmaz. Bu sebeple ilgi görmeyen ve merak uyandırmayan ama öğrencilerin öğrenmesi gereken konularda, öğrencilerin

1 İbrahim Aşlamacı, “Türkiye'nin İslam Eğitim Modeli: İmam-Hatip Okulları Ve Temel Özellikleri”, Journal of Turkish Studies 9/ (2014), 49-80.

2 Benjamin Samuel Bloom, Insan Nitelikleri ve Okulda Öğrenme, çev. Durmuş Ali Özçelik (Ankara: Pegem Akademi, 2016).

${ }^{3}$ Mehmet Şişman, Eğitim Bilimine Giriş (Ankara: Pegem Akademi, 2008), 186. 
öğrenmeye motive edilmeleri gerekmektedir. ${ }^{4}$

Öğrenciler arası bireysel öğrenme farklılıklarının ortaya çıkmasına yol açan veya bu farklılıkları görünür hale getiren yegâne unsur, okuldur. Okulda uygulanan eğitim-öğretim programı ve yöntemleri, sınıflarda tek tip eğitim verilmesi, hiç kuşkusuz bazı öğrencilerin öğrenmelerinde etkili olabilirken, bir kısım öğrencinin de öğrenmelerini zorlaştırmakta veya öğrenimlerinde etkisiz kalmaktadır. Okul bu sorunun sebebi olduğu gibi çözümünün de merkezi olmak durumundadır, aksi halde öğrenciler arası bireysel öğrenme farklılıkları her geçen gün katlanarak artacaktır. Hem bu nedenle hem de eğitimin zorunlu olması, okulların sorumluluklarını arttırmıştır. Çocuklar okula devam etmek zorundadırlar ve alternatifleri yoktur. Bu noktada okul, öğrencilerin istenen hedefe dönük eğitim almaları ve bu eğitim sonunda istenen öğrenmelerin gerçekleşmesi için öğrencileri motive etmek zorundadır. Eğer bu gerçekleştirilemez ve öğrenci istenilen yönde değil de istenmeyen yönde (çeteleşme, ahlaksızlığı öğrenme v.b.) motive olursa, öğrencilerin aldığı eğitim planlananın ve istenenin dışında olacağından, okul, telafisi olmayacak çok ağır bireysel ve toplumsal sorunların merkezi haline gelecektir. ${ }^{5}$

Ortaokul, öğrencilerin ilk defa gördükleri ve alıştıkları ilkokul ortamı ve eğitim tarzından farklı bir okul ortamına ve eğitim tarzına sahip olduğu için öğrencilerin motive olmakta en çok zorlandıkları dönemdir. ${ }^{6} \mathrm{Bu}$ dönemde çocuklar ilkokuldan ortaokula geçerken motivasyon ve performans kaybı yaşayabilmektedir. Öğrencilerin tamamının motivasyonunu ve performansını arttıracak genel bir yaklaşım ortaya koymak imkansıza yakın olsa da çoğu öğrenci için bunu başarabilecek bir yaklaşım deseni geliștirilebilir. ${ }^{7}$ Öğrencilerin bu zor dönemi, başarıyla atlatmaları, okula ve eğitime dair motive olmalarıyla paralellik gösterir. Bu çalışma, imam hatip ortaokullarında öğrenim gören öğrencilerin okul motivasyonunun farklılaştığı değişkenleri belirlenmeyi amaçlaması ve böylece imam hatip ortaokullarında verilen eğitimin planlanan ve istenen yönde olması için veriler ve öneriler sunması açısından önemlidir.

İmam hatip ortaokuluna kayıt yaptıran öğrencilerin yaşları 10-11 yaş aralığındadır. $\mathrm{Bu}$ yaşlardaki bir birey ne tamamen çocuktur ne de tam bir gençtir. $\mathrm{Bu}$ dönemde hem çocukluk hem de gençlik bir aradadır. Bir anlamda çocuk hem bedenen hem zihnen gençliğe hazırlanmaktadır. 13-14 yaşına kadar devam eden bu dönem "ilk gençlik" veya "ilk ergenlik" olarak adlandırılmaktadır. Bu dönemin öne çıkan iki özelliği bulunmaktadır. Bunlar: Bilgiye düşkünlük ve fiziki gücün zirvede olmasıdır. Bilgi ve güç birlikte, çocuklarda bencillik duygularını ortaya çıkarmaktadır. Bu bencilliğin bir sonucu olarak, büyükler için "yaramazlık" ve "haylazlık" olan, pervasız hareket ve davranışlar bu dönemde daha sık görülmektedir. ${ }^{8} \mathrm{Bu}$ da

\footnotetext{
${ }^{4}$ Ziya Selçuk, Gelişim ve Öğrenme (Ankara: Nobel Yayın Dağıtım, 2001), 209-210.

${ }^{5}$ Bloom, İnsan Nitelikleri ve Okulda Öğrenme, 9.

${ }^{6}$ Rolland Viau, Okulda Motivasyon Okulda Güdüleme ve Güdülenmeyi Öğrenme, çev. Yusuf Budak (Ankara: Anı Yayıncılık, 2015), 67.

${ }^{7}$ Carol Midgley, Motivation and Middle Level Schools (Greenwich: CT:JAI Press, 1993).

${ }^{8}$ Beyza Bilgin - Mualla Selçuk, Din Öğretimi ve Özel Öğretim Yöntemleri (Ankara: Gün Yayıncılık, 1999), 81.
} 
öğrencilerde hedefe uygun motivasyon oluşturulmasını zorlaştırmakta ve bazı disiplin sorunlarının ortaya çıkmasına sebep olabilmektedir.

Motivasyon eksikliğinin ilk göstergesi akademik başarının düşmesidir. Öğrenciler etkinliklere karşı dikkatsiz ve isteksizdirler. Bu dikkatsizlik ve isteksizlik düşük notlara sebep olur. Bütün bunların altında kendini değerli bulma duygusu yatmaktadır. Öğrenci, yaparak başarısız olup değersizlik duygusu yaşamaktansa, hiç yapmamayı seçer. Bu devam ettikçe başarısız olma kaygısı daha da artmaya başlar. Öğretmenlerinin yapacağı küçük yardımlar sayesinde öğrenci, kolaylıkla yeniden motive olabilecek ve içine düştügü bu kısır döngüden çıkabilecektir. ${ }^{9}$

Okul ortamı özel bir öneme sahiptir; öğrencilerin zamanlarının önemli bir bölümünü geçirdikleri yer okul ortamıdır. Bu nedenle okul ortamı, ailenin dışında, kendi gelişen değerlerinin ve hedeflerinin önemini ölçmek için sosyal, entelektüel ve ahlaki referans noktaları sunar. ${ }^{10}$ Okulu, öğrencilerin içinde yaşadıkları kültürden ve geçmişteki kültürel yaşantılarından faydalanacakları şekilde hazırlamak, öğrencilerin okul motivasyonunu artıracak ve okulu öğrenciler için daha anlamlı kllacaktır. ${ }^{11}$

Öğrencilerin öğrenmelerinde mutlaka kendi özgeçmişleri, aile yapıları gibi okullar tarafından çok da müdahale edilemeyecek çok yönlü birçok husus vardır. $\mathrm{Bu}$ hususların hepsi öğrencilerin motivasyonları ve öğrenmeleri üzerinde ayrı ayrı etki etmektedir. Bu farklılıklara rağmen, okulun öğrenciler için motive edici şartlar sağlayabilmesi gerekir. ${ }^{12}$ Okul motivasyonu öğrencinin, okula devamını, derslere olan ilgisini ve başarısını, performansını, geleceğe dair hedeflerini ve mutluluğunu etkileyen, aynı zamanda bunlardan da etkilenen önemli bir faktördür.

Motive olmuş öğrenci;

- Okula karşı pozitiftir ve okulu tatmin edici bulur.

- Zorlandığı görevlerde ısrarcı davranır.

- Daha az disiplin sorunlarina neden olur.

- Sunulan bilgileri derinlemesine anlamlandırır. ${ }^{13}$

Bütün bunların yanında motive olmuş öğrenci, sınıf yönetimini kolaylaștırır, öğretmenlerine işlerini iyi yaptıkları duygusunu yaşatarak iş doyumu sağlar ve diğer öğrencilere model olur. Motive olmuş öğrencinin bu davranışı, iç motivasyon, dış motivasyon veya hem iç hem de dış motivasyon kaynaklı olabilmektedir. ${ }^{14}$

Din eğitimi açısından konuya bakıldığında, çocuğun ilk dini tecrübelerini ve yaşantılarını edindiği yer ailesidir. Çocuk burada iyi veya kötü, doğru veya yanlış birçok dini tecrübe edinerek okula gelmektedir. Okul, iyi ve doğru olan tecrübeleri

\footnotetext{
${ }^{9}$ Ziya Selçuk - Nedret Güner, Sınıf İçi Rehberlik Uygulamaları (Ankara: Pegem Yayıncılık, 2003), 71.

${ }^{10}$ Alexander Seeshing Yeung - Dennis M. McInerney, "Students' School Motivation and Aspiration Over High School Years", Educational Psychology 25/5 (01 Ekim 2005), 504.

${ }^{11}$ Anita Woolfolk, Eğitim Psikolojisi, çev. Duygu Özen (İstanbul: Kaknüs Yayınları, 2015), 819.

12 Bloom, Insan Nitelikleri ve Okulda Öğrenme, 10.

${ }^{13}$ Deborah J. Stipek, Motivation To Learn: From Theory To Practice (Boston - US: Allyn ve Bacon, 1998).

14 Galip Yüksel, “Öğrenme İçin Motivasyon”, Sınıf Yönetimi, ed. M. Çağatay Özdemir (Ankara: Pegem Akademi, 2017), 18.
} 
pekiștirmek, kötü ve yanlıș olan tecrübeleri de iyi ve doğru olan dini bilgi ve yaşantılarla ikame etmek durumundadır. Okul, çocukta var olan içsel motivasyon sonucu ortaya çıkan inanma ve inandığına göre yaşama potansiyelini, dışsal motivasyonlar ile destekleyerek dine dair öğrenme ve öğrendiği bilgiler doğrultusunda yaşantılar oluşturabilmesi için ortam sağlamalıdır. Okul bu yaşantıların adeta laboratuvarı olmalıdir.

$\mathrm{Bu}$ çalışmada öğrencilerin, demografik ve sosyo-ekonomik özellikleri, öğrenci din eğitimi geçmişi ve almakta olduğu eğitim ile gelecekten beklentilerinin, öğrencinin okul motivasyonlarında farklılaşmaya neden olup olmadığı tespit edilmeye çalışılacaktır. Burada amaç bireysel farklılıkları ön plana çıkartmak değil, öğrencinin içinde bulunduğu imkânların ve sahip olduğu firsatların, eğitim ve din eğitimine dair motive ediciliğini belirlemektir. Din ile ilgili dersleri veren öğretmenlerin din hakkında doğru bilgiye ve yeterliliğe sahip olması gerektiği gibi ders verdiği öğrencilerin özelliklerini bilmesi ve buna göre motive edici faaliyetler geliştirmesi gerekmektedir. ${ }^{15}$

İmam hatip ortaokulu öğrencileri hem din eğitimi almakta hem de akademik eğitimlerini sürdürmektedir. İmam hatip ortaokullarında, her derste olduğu gibi din ile ilgili derslerde de öğrenciye yönelik hedefler yani kazanımlar ortaya koymakta ve bu kazanımlara göre programlar hazırlanmaktadır. ${ }^{16}$ Öğrencilerin motivasyonlarını arttırmak için birçok çalışma yapılmaktadır. Ancak alanyazında imam hatip ortaokulu öğrencilerinin motivasyonlarının farklılaștığı değișkenleri inceleyen bir çalıșmaya rastlanmamıştır. İmam hatip ortaokullarının diğer ortaokullardan farkl, diğer ortaokullarda seçmeli olarak verilen din ile ilgili derslerin imam hatip ortaokullarında zorunlu dersler olarak verilmesidir. Bu okullara gelen öğrencinin ve çocuklarını bu okullara gönderen velilerin diğer ortaokullara göre beklentileri ve hedefleri farklılaştığı söylenebilir. Öğrencilerin dini anlayışlarının ve bilgilerinin oluştuğu, velilerin akademik başarının yanı sıra din eğitimini öncelediği bu okullarda öğrenim gören öğrencilerin okul motivasyonu düzeylerinde farklılık oluşturan değişkenlerin belirlenmesini amaçlayan bu çalışmanın, alanyazına önemli bir katkı sağlayacağı düşünülmektedir.

$\mathrm{Bu}$ araștırma, imam hatip ortaokullarında okuyan öğrencilerin okul motivasyonlarında hangi değişkenlerin farklılaşmaya neden olduğunu ortaya koymak suretiyle, okullara ve bu okullarda görev yapan öğretmenlere veri sunmayı amaçlamaktadır. Bu amaç doğrultusunda hazırlanmış olan kişisel bilgi formu ile öğrencilerin profili belirlenmeye çalışılmış, okul motivasyon ölçeği ile de okul motivasyonu düzeyleri tespit edilerek, bu değişkenler arasında farklılık olup olmadığı istatiksel olarak analiz edilmiştir.

Bu araștırma, 2018-2019 eğitim-öğretim yılı bahar yarıyılında Erzurum ilinin merkez ilçeleri olan Yakutiye, Palandöken ve Aziziye İlçelerinde bulunan imam

15 Eyüp Şimșek, İlköğretim Din Kültürü ve Ahlak Bilgisi Dersi Öğretmenlerinin Yeterlikleri (Erzurum Örneği) (Erzurum: Atatürk Üniversitesi, Doktora Tezi, 2006).

16 Tecelli Karasu, “İmam Hatip Meslek ve Dikap Dersi Öğretmenlerinin Eğitim Bilișim Ağı (EBA) İle İlgili Görüşleri”, Bitlis Eren Üniversitesi Sosyal Bilimler Dergisi $7 / 2$ (21 Aralık 2018), 937. 
hatip ortaokullarında öğrenim gören 5., 6., 7. ve 8. sınıf öğrencilerden tesadüfi olarak seçilen örneklemle ve kişisel bilgi formunda yer alan değişkenler ve sorular ile sinırlidır.

$\mathrm{Bu}$ araștırmanın problemi, "imam hatip ortaokullarında okuyan öğrencilerin okul motivasyonlarında hangi değişkenler farklılaşmaya neden olmaktadır?" şeklinde belirlenmiştir. Bu temel problem çerçevesinde ortaya çıkan alt problemler şu şekilde oluşmuştur;

- İmam hatip ortaokullarında okuyan öğrencilerin okul motivasyonları, cinsiyetlerine göre anlamlı farklılaşmakta mıdır?

- İmam hatip ortaokullarında okuyan öğrencilerin okul motivasyonları, okudukları sınıflara göre farklılaşmakta mıdır?

- İmam hatip ortaokullarında okuyan öğrencilerin okul motivasyonları, anne eğitim durumuna göre farklılaşmakta mıdır?

- İmam hatip ortaokullarında okuyan öğrencilerin okul motivasyonları, baba eğitim durumuna göre farklılaşmakta mıdır?

- İmam hatip ortaokullarında okuyan öğrencilerin okul motivasyonları, okula kayıt nedenlerine göre farklılaşmakta mıdır?

- İmam hatip ortaokullarında okuyan öğrencilerin okul motivasyonları önceki Kur'an-ı Kerim okuma bilgisine göre farklılaşmakta mıdır?

- İmam hatip ortaokullarında okuyan öğrencilerin okul motivasyonları, imam hatip lisesine devam isteğine göre farklılaşmakta mıdır?

\section{Yöntem}

\subsection{Araștırmanın Modeli}

$\mathrm{Bu}$ araştırma, nicel araștırma yöntemlerinden tarama modeline göre tasarlanmıştır.

Tarama modelleri, bir durumu, geçmişte ya da şu anda var olduğu haliyle tespit etmeyi ve betimlemeyi amaçlayan araştırma modellerdir. Araștırmaya konu olan durum (birey, olay, nesne v.b.) kendi ortamında var olduğu şekliyle ele alınır. Öğrenilmek istenen uygun bir şekilde gözlemlenip belgelenir. ${ }^{17}$

\subsection{Evren ve Örneklem}

Araştırmamızın evreni, 2018-2019 eğitim-öğretim yılı bahar döneminde Erzurum ili merkez ilçelerinde eğitim veren imam hatip ortaokullarıdır. Araştırmamızın örneklemi, Erzurum ili, merkez ilçeleri; Yakutiye, Palandöken ve Aziziye ilçelerinde bulunan imam hatip ortaokulları içerisinden, evrendeki bütün elemanların eşit seçilme şansına sahip olduğu basit tesadüfi (oransız eleman) örnekleme ${ }^{18}$ ile belirlenen gönüllü erkek ve kız öğrencilerdir. Örneklem için seçilen bu okulların

\footnotetext{
17 Niyazi Karasar, Bilimsel Araştırma Yöntemi: Kavramlar İlkeler Teknikler (Ankara: Nobel, 2018), 109.

${ }^{18}$ Karasar, Bilimsel Araştırma Yöntemi: Kavramlar Illkler Teknikler.
} 
bulundukları ilçenin nüfusu, sosyo-ekonomik yapısı dikkate alınmak suretiyle eşit örneklem dağılımı sağlanmaya çalışılmıştır. Erzurum İli Merkez ilçelerinde bulunan imam hatip ortaokullarında toplamda 4832 öğrenci eğitim görmektedir. Örneklem sayısı .05 hata payı ${ }^{19}$ dikkate alınarak hesaplanmış ve sağlıklı sonuçlar elde edilebilmesi için örneklemin en az 356 katılımcıdan oluşması gerektiği anlaşılmıştir.

Tablo 1.1. Çalışma Kapsamında Ulaşılan Toplam Katılımcı Sayısı

\begin{tabular}{lcc}
\hline & Frekans & \% \\
\hline Erkek & 461 & 48,1 \\
Kiz & 497 & 51,9 \\
Toplam & 958 & 100 \\
\hline
\end{tabular}

Belirlenen örneklem sayısına ulaşabilmek için 461'i (\%48,1) erkek, 497'i $(\% 51,9) \mathrm{kız}$ olmak üzere 958 öğrenciye ulaşılmış ve veri toplama araçları dağıtılmıştır. Dağıtılan veri toplama araçları, veri analizi öncesi veri ayıklama işlemine tabi tutulmuştur. Veri ayıklama işlemi sonucunda normallik şartının sağlanabilmesi de dikkate alınarak eksik ve özensiz doldurulan 180 tane veri toplama aracı analiz öncesinde çıkarılmıştır.

Tablo 1.2. Örneklem Grubunun Cinsiyete Göre Dağılımı

\begin{tabular}{lcc}
\hline & Frekans & \% \\
\hline Erkek & 370 & 47,6 \\
Kiz & 408 & 52,4 \\
Toplam & 778 & 100 \\
\hline
\end{tabular}

Veri analize tabi tutulan örneklem grubu 370'i \%(47,6) erkek, 408'i $(\% 52,4)$ kız olmak üzere toplam 778 öğrenciden oluşmuştur.

\subsection{Veri Toplama Araçları}

\subsubsection{Kişisel Bilgi Formu}

Kişisel bilgi formu araştırmacı tarafından, araştırmanın ana problemi kapsamında, katılımcılara ait bilgileri talep etmek için hazırlanmıştır. Formda sosyoekonomik, demografik değişkenler (cinsiyet, sınıfl, ebeveynlerinin eğitim durumu) ve öznel bağımsız değişkenler (öğrencilerin okul tercih nedenleri, Kur'an-ı Kerim okuma bilgisi, lise tercih durumları) ile ilgili sorular bulunmaktadır.

\subsubsection{Ortaokul Öğrencileri İçin Okul Motivasyon Ölçeği (OMÖ-ORT)}

Kaynak, Özhan ve Kan (2017) tarafından geliştirilen, ortaokulda öğrenim gören öğrencilerin okul motivasyonu düzeylerini ölçmek amaciyla ortaokul öğrencilerinin davranışsal, bilişsel ve duyuşsal özellikleri göz önüne alınarak hazırlanan ölçek, 14 sorudan oluşan 5'li likert tipi derecelendirme ölçeğidir. 3., 9., 13. madde-

\footnotetext{
${ }^{19}$ Robert V. Krejcie - Daryle W. Morgan, “Determining Sample Size for Research Activities”, Educational and Psychological Measurement 30/3 (Eylül 1970), 607-610.
} 
ler ters puanlanan maddelerdir. Ölçekten alınan puanlar arttıkça, öğrencinin okul motivasyonu düzeyi de artmaktadır. Ölçekten alınabilecek en yüksek puan 70'tir. Ölçek, okul motivasyonu düzeyi hakkında hedef, performans ve okula bağlllık olmak üzere üç farklı boyutta ölçme yapmaktadır. ${ }^{20}$

\subsubsection{1. Ölçeğin Geçerliliği}

Ölçek geliştiricisi tarafından Ankara ve Erzurum İllerinde bulunan 4 farklı ortaokulda öğrenim gören 370 öğrenciye testler uygulanmıştır. Bu uygulama sonucunda OMÖ-ORT formunun alt boyutlarıyla beraber okul motivasyonuna ilișkin toplam varyansın \%68.665'ini açıklamakta olduğu görülmüştür. Ölçeğin doğrulayıCl faktör analizi (DFA) sonuçları; $\mathrm{x}^{2} / \mathrm{df}=2.963$, CFI=.952, TLI/NNFI=.939, GFI=.920, AGFI=.883, RMSEA=.076 [\%90 CI: .064 - .087] olarak hesaplanmıștır. ${ }^{21}$ Bu çalışmada ise $\mathrm{x}^{2} / \mathrm{df}=4.76, \mathrm{CFI}=.826$, TLI/NNFI=.993, GFI=.937, AGFI=.910, RMSEA $=.070$ [\%90 CI: .062 - .077] olarak hesaplanmıştır ve Wheaton v.d'ne (1977) göre $\mathrm{x}^{2} / \mathrm{df} \leq$ 5 olması ölçeğin geçerliliği için uygun bir değerdir.

\subsubsection{2. Ölçeğin Güvenilirliği}

Ortaokul Öğrencileri İçin Okul Motivasyon Ölçeği (OMÖ-ORT) geliştirme çalışmasında, ölçek maddelerinin tamamı için yaptığı testte Cronbach Alfa iç tutarlık katsayısı .84 olduğu görülmektedir. $\mathrm{Bu}$ araştırmada maddelerin tamamının Cronbach Alfa iç tutarlık katsayısı 75 olarak hesaplanmıştır. Cronbach Alfa iç tutarlık katsayısı .70 olması, psikolojik ölçme aracının güvenirliği için yeterli görülmektedir. ${ }^{22}$

\subsection{Uygulama ve İşlem}

Veri toplama araçları ile elde edilen veriler, araştırmacı tarafından SPSS ortamına aktarılmış ve elde edilen bulgular SPSS 20.0 (Statistical Package for Social Sciences) bilgisayar istatistik paket programıla analiz edilmiştir.

Ortaokul öğrencileri için okul motivasyonu ölçeğine ait örneklem büyüklügü, en düşük ve en yüksek okul motivasyonu düzeyi, aritmetik ortalama, standart sapma, çarpıklık ve basıklık değerlerine ilişkin bulgulara Tablo 1.3'te yer verilmiştir.

\footnotetext{
${ }^{20}$ Semih Kaynak vd., “Ortaokul Öğrencileri İçin Okul Motivasyonu Ölçeği Geliştirme Çalışması”, Journal of Turkish Studies 12/ (01 Ocak 2017), 293-312.

${ }^{21}$ Kaynak vd., "Ortaokul Öğrencileri İçin Okul Motivasyonu Ölçeği Geliștirme Çalıșması”.

${ }^{22}$ Kaynak vd., "Ortaokul Öğrencileri İçin Okul Motivasyonu Ölçeği Geliştirme Çalışması”.
} 
Tablo 1.3. Örneklem Grubunu Oluşturan Öğrencilerin Toplam Okul Motivasyonu Düzeyleri

\begin{tabular}{llllclll}
\hline & $\mathbf{N}$ & Min & Max & $\overline{\mathbf{x}}$ & ss & Kurtosis & Skewness \\
\hline $\begin{array}{l}\text { Ortaokulu Öğrencileri İçin } \\
\text { Okul Motivasyonu Ölçeği }\end{array}$ & 778 & 40 & 70 & 59,43 & 6,529 & -.403 & -.424 \\
\hline
\end{tabular}

Araștırmada verilerin analiz edilme sürecinde hangi testlerin kullanılacağ $\breve{1}^{-}$ na karar verebilmek amacıyla parametrik testlerin temel varsayımlarını karşılayıp karşılayamadıkları incelenmiştir. Örneklem gruplarının normal dağılım gösterip göstermediğini belirlemek için normallik testi yapılarak Skewness (çarpıklık) ve Kurtosis (basıklık) değerlerine bakılmıştır. Skewness değeri -.403, Kurtosis değeri ise -.424 olduğu gözlenmiştir. Kurtosis ve Skewness değerleri -1.5 ile +1.5 olduğu zaman normal dağılım olduğu kabul edilmektedir. ${ }^{23}$

Yapılan ölçümler doğrultusunda; araştırmada iki alt kategoriye sahip Bağımsız Değişkenler için t-Testi (Independent-Samples t-Test) kullanılmış, ikiden fazla alt kategoriye sahip bağımsız değişkenler için ise, Tek Yönlü Varyans Analizi (One-Way ANOVA) testi uygulanmıştır. ANOVA testi ile yapılan analizler sonucunda, grupların ortalama puanları arasında farklılık tespit edilmişse bu farklılığın hangi gruplardan kaynaklandığını bulabilmek için Levene Testi yapılarak varyansların homojenliğine bakılmıştır. Eşit örneklem sayısı sağlanamadığında ve varyansların homojenliğini gerektirmesi nedeniyle Post Hoc. Bonferroni tercih edilmiştir. Eşit örneklem sayısı gerektirmemesi ve varyansların homojenliği sağlanmadığında ise Games-Howell testi kullanılmıştır. ${ }^{24}$

\section{Bulguların Yorumlanması}

\section{1. İmam Hatip Ortaokullarında Okuyan Öğrencilerin Cinsiyetlerine Göre OMÖ-ORT Puanlarına İlişkin Bulguların Yorumlanması}

İmam hatip ortaokullarında okuyan kız ve erkek öğrencilerin OMÖ-ORT puanlarının farklı olup olmadığını tespit etmek için bağımsız t-testi analizi sonucunda elde edilen bulgular aşağıda sunulmuştur.

Tablo 2.1. İmam Hatip Ortaokullarında Okuyan Erkek ve Kız Öğrencilerin OMÖ-ORT Puanlarının Ortalamaları Arasındaki Farklılık (Bağımsız T-Testi)

\begin{tabular}{lcccccccc}
\hline \multicolumn{1}{c}{ Değişken } & Cinsiyet & $\mathbf{n}$ & $\mathbf{\%}$ & $\overline{\mathbf{x}}$ & $\mathbf{s s}$ & $\mathbf{t}$ & $\mathbf{s d}$ & $\mathbf{p}$ \\
\hline $\begin{array}{l}\text { OMÖ-0RT } \\
\text { Toplam }\end{array}$ & Erkek & 370 & 47,6 & 58,74 & 6,65 & & & \\
\cline { 2 - 8 } Motivasyon & $\mathrm{Kiz}$ & 408 & 52,4 & 60,06 & 6,35 & & & \\
\hline
\end{tabular}

Tablo 2.1'e bakıldığında bağımsız örneklem t testi sonuçlarına göre erkek öğrencilerin OMÖ-ORT puanları ortalaması ( $\overline{\mathrm{x}}=58.74)$ ile kız öğrencilerin OMÖ-

${ }^{23}$ Linda S. Fidell - Barbara Tabachnick, Çok Değişkenli İstatistiklerin Kullanımı, çev. Mustafa Baloğlu (İstanbul: Nobel Akademik Yayıncılık, 2015).

${ }^{24}$ Murat Kayri, "Araștırmalarda Gruplar Arası Farkın Belirlenmesine Yönelik Çoklu Karşılaștırma (PostHoc) Teknikleri”, Fırat Üniversitesi Sosyal Bilimler Dergisi 19/1 (2009), 51-64. 
ORT puanları ortalaması $(\overline{\mathrm{x}}=60,06)$ arasında istatistiksel olarak kız öğrencilerin lehine anlamlı bir farklılık görülmektedir $[\mathrm{t}(776)=-2,84, \mathrm{p}<.05]$.

Erkan (2019) tarafından yapılan imam hatip ortaokullarında öğrencilerinin motivasyon düşüklüğünün sebeplerini araştırdığı çalışmada öğrencilerin motivasyon düzeylerinin cinsiyete göre farklılaşmadığı görülmektedir. ${ }^{25} \mathrm{Bu}$ araştırmada imam hatip öğrencilerinin okul motivasyonları cinsiyete göre anlamlı farklılık göstermektedir. Bu durum; öğrencilerin cinsiyetlerinin, okul motivasyonunda farklılığa neden olan bir değişken olarak ele alınabileceği şeklinde yorumlanabilir. Alanyazına bakıldığında motivasyon ve cinsiyet arasında farklılaşma tespit edilmemiş olsa da bu çalışmada bir farklılık oluşturduğu görülmektedir. Bu farklılığın oluşmasında hormonal ve biyolojik yapının önemli etken olabileği bilinmektedir. Fakat bu durumun tek başına bu farklılaşmada rol oynadığı söylenemez. Çünkü, içerisinde yaşanılan toplumun kültürel özelliklerinin, çocukların benimsedikleri cinsiyet rolleri üzerinde etkili olduğunu ortaya koymuş birçok çalışma bulunmaktadır. ${ }^{26} \mathrm{Bu}$ araştırmada da farklılığın ortaya çıkmasında biyolojik ve hormonal farklılıkların yanında sosyal öğrenmeler sonucu çocuğun öğrendiği cinsiyet rolleri de etkili olmuş olabilir. Toplumumuzda halen baskın bir şekilde var olan geleneksel aile yaşamı erkek ve kız çocuklarına farklı roller sunmaktadır. Kız çocuklarının aileden öğrendiği tesettür gibi hem geleneksel hem de dini inaca dayanan tercihleri, imam hatip ortaokuluna dair okul motivasyonları üzerinde etkili olmuş olabilir. $\mathrm{Bu}$ konuda daha fazla çalışma yapılması gerekmektedir.

\section{2. İmam Hatip Ortaokullarında Okuyan Öğrencilerin Okudukları Sınıflara Göre OMÖ-ORT Puanlarına İlişkin Bulguların Yorumlanması}

İmam hatip ortaokullarında okuyan öğrencilerin okudukları sınıflara göre OMÖ-ORT puanlarına bakılmış ve bu puanlar arasında istatistiksel olarak anlamlı bir farkın olup olmadığını tespit etmek için Tek Yönlü Varyans Analizi (ANOVA) uygulanmıştır. İstatistiksel olarak anlamlı bir farklılık tespit edilmiş ve (Post-Hoc) Bonferroni testi uygulanmıștır. Testlerle ilgili bulgular aşağıdaki tabloda sunulmuştur.

25 Durmuş Erkan, Öğrenci Gözüyle Imam Hatip Ortaokullarında Motivasyon Düşüklüğünün Sebepleri: Karabağlar Örneği (İzmir: Dokuz Eylül Üniversitesi, Yüksek Lisans Tezi, 2019).

${ }^{26}$ Hülya Çakir - Hatice Baş, "Cinsiyetler ve Cinsiyetlerle Özdeşleşen Davranışların Sosyolojik ve Biyolojik Açıdan Değerlendirilmesi”, (2018), 176-191. 
Tablo 2.2. İmam Hatip Ortaokullarında Okuyan Öğrencilerin Okudukları Sınıflara Göre OMÖORT Puanları Arasındaki Farklılığa İlişkin Yapılan Tek Yönlü Varyans Analizi (ANOVA) Sonuçları

\begin{tabular}{lcccccccc}
\hline Değişken & $\mathbf{n}$ & $\mathbf{\%}$ & $\overline{\mathbf{x}}$ & $\mathbf{s s}$ & $\mathbf{s d}$ & $\mathbf{F}$ & $\mathbf{p}$ & Anlamlı Fark \\
\hline $\mathbf{5}$ & 235 & 30,2 & 61.31 & 6,278 & $3 / 774$ & 10,36 &, 00 & \\
$\mathbf{6}$ & 172 & 22,1 & 59.13 & 6,809 & & & & $5-6$ \\
$\mathbf{7}$ & 231 & 29,7 & 58.17 & 6,461 & & & & $5-7$ \\
$\mathbf{8}$ & 140 & 18 & 58.73 & 6,052 & & & & $5-8$ \\
Toplam & 778 & 100 & 59.43 & 6,529 & & & & \\
\hline
\end{tabular}

Tablo 2.2. incelendiğinde p değeri 0,05'ten küçük olduğu görülmektedir. $\mathrm{Bu}$ da sinıflar arasında anlamlı bir farklılığın olduğunu göstermektedir [F(3774)=10,36, p<.05]. Bu farklılığın hangi sınıflar arasında olduğunu tespit etmek için çoklu karşılaştırma testlerinden (Post-Hoc) Bonferroni testi uygulanmıştır. Test sonuçlarına bakıldığında anlamlı farkın, 5. sınıfla $(\overline{\mathrm{x}}=61,31)$ 6. sinıf $(\overline{\mathrm{x}}=$ $59,13)$ arasinda $(\mathrm{p}<.05), 5$. sinifla $(\overline{\mathrm{x}}=61,31)$ 7. sinıf $(\overline{\mathrm{x}}=58.17)$ arasinda $(\mathrm{p}<.05)$ ve 5. sinıfla $(\bar{x}=61,31)$ 8. sinıf $(\bar{x}=58,73)$ arasında $(p<.05)$ olduğu tespit edilmiştir. Farklılığın yönüne bakıldığında farklılığın 5. sınıflar lehine olduğu görülmüştür.

İmam hatip ortaokuluna yeni başlayan öğrencilerin okul motivasyonlarının yüksek olduğu görülmektedir. Sınıf değişkeninin okul motivasyonunda farklılaşmaya yol açan bir değişken olarak ele alınabileceği söylenebilir. Okula yeni başlayan öğrencilerin okul motivasyonları yüksektir. Bu farklılığın oluşmasında, yeni bir okula başlamanın heyecanının ve öğrencilerin istekli olmasının önemli rol oynadığı söylenebilir. Bununla beraber ilerleyen sınıflarda ders konularının ağırlaşması nedeniyle öğrencinin dersi anlamakta zorluklarla karşılaşması ve bu zorlukları aşması için gerekli motivasyonun sağlanamaması (öğretmenlerin tutumu, kullanılan materyaller, eğitim programı vb.) da etkili olmuş olabilir. Ayrıca, ortaokul döneminin son çocukluktan ergenliğe geçiş dönemine denk gelmesi nedeniyle, öğrencilerin derslere dair olan ilgilerinin farklı yönlere kayması da bu farklılaşmada etkili olmuş olabilir. Bu durumlarda öğrencinin bilme, öğrenme ve kendini tatmin isteği, sınıf içi etkinliklerle desteklenerek, derslere yönelik içsel ve dışsal motivasyonu arttırılmalıdır. İlgili alanyazında da benzer sonuçlar olduğu görülmektedir. ${ }^{27}$

\section{3. İmam Hatip Ortaokullarında Okuyan Öğrencilerin Anne Eğitim Duru- muna Göre OMÖ-ORT Puanlarına İlişkin Bulguların Yorumlanması}

İmam hatip ortaokullarında okuyan öğrencilerin anne eğitim durumuna göre OMÖ-ORT puanlarına bakılmış ve bu puanlar arasında istatistiksel olarak anlamlı bir farkın olup olmadığını tespit etmek için Tek Yönlü Varyans Analizi (ANOVA) uygulanmıştır. Testlerle ilgili bulgular aşağıdaki tabloda sunulmuştur.

\footnotetext{
${ }^{27}$ Erkan, Öğrenci Gözüyle Imam Hatip Ortaokullarında Motivasyon Düşüklüğünün Sebepleri: : Karabağlar Örneği.
} 
Tablo 2.3. İmam Hatip Ortaokullarında Okuyan Öğrencilerin Anne Eğitim Durumuna Göre OMÖ-ORT Puanları Arasındaki Farklılığa İlişkin Yapılan Tek Yönlü Varyans Analizi (ANOVA) Sonuçları

\begin{tabular}{lcccccccc}
\hline \multicolumn{1}{c}{ Değişken } & $\mathbf{n}$ & $\mathbf{\%}$ & $\overline{\mathbf{x}}$ & $\mathbf{s s}$ & $\mathbf{s d}$ & $\mathbf{F}$ & $\mathbf{p}$ & $\begin{array}{c}\text { Anlamlı } \\
\text { Fark }\end{array}$ \\
\hline $\begin{array}{l}\text { Okur-Yazar } \\
\text { Değil }\end{array}$ & 68 & 8,7 & 59.62 & 6,067 & $5 / 772$ & 1,137 &, 339 & \\
İlkokul & 320 & 41,1 & 59,91 & 6,556 & & & & \\
Ortaokul & 241 & 31 & 59,33 & 6,532 & & & \\
Lise & 98 & 12,6 & 58,74 & 6,737 & & & \\
Üniversite & 41 & 5,3 & 57,80 & 6,532 & & & \\
Lisansüstü & 10 & 1,3 & 58,50 & 6,311 & & & \\
Toplam & 778 & 100 & 59.43 & 6,529 & & & \\
\hline
\end{tabular}

Tablo 2.3 incelendiğinde p değeri $0,05^{\prime}$ ten büyük olduğu görülmektedir. Bu da anne eğitim durumları arasında anlamlı bir farklılı̆̆ın olmadığını göstermekte$\operatorname{dir}[\mathrm{F}(5-772)=1,137, \mathrm{p}>.05]$. Bu durum; öğrencilerin anne eğitim durumu değişkeninin, öğrencilerin okul motivasyonunda farklılık oluşturan bir değişken olarak ele alınamayacağı söylenebilir.

Anne eğitim durumu ve motivasyon düzeyi ile ilgili alanyazına bakıldığında; Bahtiyar \& Can (2017) tarafından yapılan çalışmada bu çalışmanın sonuçlarıyla uyumlu bir şekilde anne eğitim durumu öğrencilerin motivasyon düzeylerinde farklılık oluşturmamıştır. ${ }^{28}$ Fakat Yerlikaya (2014) tarafından yapılan çalışmada ise anne eğitim durumu öğrencilerin motivasyon düzeylerinde farklllık oluşturmuştur. Bu farklılı̆̆ın ortaya çıkmasında araştırmacının ilkokulları da kapsayan bir araştırma yapmış olmasının etkili olmuş olabileceği söylenebilir. ${ }^{29} \mathrm{Bu}$ araştırmanın başında, anne eğitim durumunun okul motivasyonunda farklılık oluşturacağı beklentisi hakimdir. Çünkü annenin eğitim düzeyi arttıkça çocuğun akademik gelişimini daha verimli bir şekilde destekleyeceği ve bunun da öğrencinin okul motivasyonunu olumlu etkileyeceği düșünülmüștür. Fakat, çalıșma sonucunda anne eğitim düzeyinin okul motivasyonunda farklılık oluşturmadığı tesbit edilmiştir. Anne eğitim durumunun öğrencinin okul motivasyonunda farklılık oluşturmamasının nedenleri üzerine daha fazla çalışma yapılması gerekmektedir.

\section{4. İmam Hatip Ortaokullarında Okuyan Öğrencilerin Baba Eğitim Duru- muna Göre OMÖ-ORT Puanlarına İlişkin Bulguların Yorumlanması}

İmam hatip ortaokullarında okuyan öğrencilerin baba eğitim durumuna gö-

\footnotetext{
${ }^{28}$ Asiye Bahtiyar - Bilge Can, "Ortaokul (5., 6., 7., ve 8. Sınıf) Öğrencilerinin Daimî Bilim Öğrenme Motivasyonlarının İncelenmesi", Pamukkale Üniversitesi Eğitim Fakültesi Dergisi 41/41 (01 Ocak 2017), 121-129.

29 İbrahim YerliKaya, "İlkokul ve Ortaokul Öğrencilerinin Eğitime İlișkin Motivasyonlarının Çeșitli Değişkenler Açısından İncelenmesi", Journal Of History School 7/XIX (01 Ocak 2014), 773-795.
} 
re OMÖ-ORT puanlarına bakılmış ve bu puanlar arasında istatistiksel olarak anlamlı bir farkın olup olmadığını tespit etmek için Tek Yönlü Varyans Analizi (ANOVA) uygulanmıștır. İstatistiksel olarak anlamlı bir farklılık tespit edilmiş ve (Post-Hoc) Bonferroni testi uygulanmıştır. Testlerle ilgili bulgular aşağıdaki tabloda sunulmuştur.

Tablo 2.4. İmam Hatip Ortaokullarında Okuyan Öğrencilerin Baba Eğitim Durumuna Göre OMÖ-ORT Puanları Arasındaki Farklılığa İlişkin Yapılan Tek Yönlü Varyans Analizi (ANOVA) Sonuçları

\begin{tabular}{lcccccccc}
\hline \multicolumn{1}{c}{ Değișken } & $\mathbf{n}$ & $\mathbf{\%}$ & $\overline{\mathbf{x}}$ & $\mathbf{s s}$ & $\mathbf{s d}$ & $\mathbf{F}$ & $\mathbf{p}$ & $\begin{array}{c}\text { Anlaml } \\
\text { Fark }\end{array}$ \\
\hline Okur-Yazar & 47 & 6 & 60,96 & 6,376 & $5 / 772$ & 2,322 &, 04 & \\
Değil & 127 & 16,3 & 59,77 & 6,518 & & & & \\
İlkokul & 186 & 23,9 & 59,65 & 6,331 & & & \\
Ortaokul & 240 & 30,8 & 59,72 & 6,599 & & & \\
Lise & 147 & 18,9 & 58,42 & 6,594 & & & \\
Üniversite & 31 & 4 & 56,97 & 6,432 & & & \\
Lisansüstü & 778 & 100 & 59.43 & 6,529 & & & & \\
Toplam & & & & & & \\
\hline
\end{tabular}

Tablo 2.4. incelendiğinde p değeri 0,05'ten küçük olduğu görülmektedir. $\mathrm{Bu}$ da baba eğitim durumları arasında anlamlı bir şekilde farklılığın olduğunu göstermektedir $[\mathrm{F}(5-772)=2,322, \mathrm{p}<.05]$. Bu farklılığın hangi baba eğitim durumları arasında olduğunu tespit etmek için çoklu karşılaştırma testlerinden (Post-Hoc) Bonferroni Testi uygulanmıştır ve anlamlı bir farklılık olduğu görülmemiştir. Farklılık görülmemesinin nedeni lisansüstü eğitim düzeyine sahip babaların örneklem içerisinde sayılarının az olması olabilir. Bu durum; öğrencilerin baba eğitim durumu değişkeninin, öğrencilerin okul motivasyonunda farklılık oluşturan bir değişken olarak ele alınamayacağını göstermektedir.

Baba eğitim durumu ve motivasyon düzeyi ile ilgili alanyazına bakıldığında; Yerlikaya (2014) tarafından yapılan, ilkokulları da kapsayan çalışmada, baba eğitim durumunun motivasyon düzeylerinde farklılık oluşturduğu görülmüştür. ${ }^{30} \mathrm{Bu}$ araştırmada anne eğitim durumunda olduğu gibi baba eğitim düzeyi arttıkça öğrencinin akademik gelişimini olumlu etkileyeceği ve dolayısıyla okul motivasyonunda olumlu yönde farklılık oluşturacaği düşünülmüştür. Fakat, baba eğitim düzeyinin öğrencinin okul motivasyonunda farklılık oluşturmadığı görülmüştür. Ebeveynlerin eğitim düzeyinin öğrencinin okul motivasyonunda farklılık oluşturmamasının nedenleri üzerine daha fazla çalışma yapılması ve nedenlerinin ortaya konulması gerekmektedir.

\footnotetext{
30 YerliKaya, “İlkokul ve Ortaokul Öğrencilerinin Eğitime İlişkin Motivasyonlarının Çeşitli Değişkenler Açısından İncelenmesi”.
} 


\section{5. İmam Hatip Ortaokullarında Okuyan Öğrencilerin Okula Kayıt Neden- lerine Göre OMÖ-ORT Puanlarına İlişkin Bulguların Yorumlanması}

İmam hatip ortaokullarında okuyan öğrencilerin okula kayıt nedenlerine göre OMÖ-ORT puanlarına bakılmış ve bu puanlar arasında istatistiksel olarak anlamlı bir farkın olup olmadığını tespit etmek için Tek Yönlü Varyans Analizi (ANOVA) uygulanmıştır. İstatistiksel olarak anlamlı bir farklılık tespit edilmiş ve (Post-Hoc) Games-Howell testi uygulanmıştır. Testlerle ilgili bulgular aşağıdaki tabloda sunulmuştur.

Tablo 2.5. İmam Hatip Ortaokullarında Okuyan Öğrencilerin Okula Kayıt Nedenlerine Göre OMÖ-ORT Puanları Arasındaki Farklılığa İlişkin Yapılan Tek Yönlü Varyans Analizi (ANOVA) Sonuçları

\begin{tabular}{|c|c|c|c|c|c|c|c|c|}
\hline Değişken & $\mathbf{n}$ & $\%$ & $\overline{\mathbf{x}}$ & ss & sd & $\mathbf{F}$ & $\mathbf{p}$ & $\begin{array}{c}\text { Anlamlı } \\
\text { Fark }\end{array}$ \\
\hline Kendi isteğimle & 395 & 50,8 & 60,33 & 6,261 & $6 / 771$ & 3,584 & 00 & \multirow{8}{*}{$\begin{array}{c}\text { kendi } \\
\text { isteğiyle } \\
- \\
\text { ailesinin } \\
\text { isteğiyle }\end{array}$} \\
\hline Ailemin isteğiyle & 190 & 24,4 & 58,55 & 6,857 & & & & \\
\hline $\begin{array}{l}\text { Öğretmenimin tavsiye- } \\
\text { siyle }\end{array}$ & 9 & 1,2 & 57,67 & 8,660 & & & & \\
\hline Evime yakın olduğu için & 51 & 6,6 & 58,22 & 7,872 & & & & \\
\hline $\begin{array}{l}\text { Eğitim seviyesi iyi oldu- } \\
\text { ğu için }\end{array}$ & 89 & 11,4 & 59,46 & 5,508 & & & & \\
\hline $\begin{array}{l}\text { Arkadaşlarım bu okula } \\
\text { kaydolduğu için }\end{array}$ & 10 & 1,3 & 55,10 & 4,977 & & & & \\
\hline Diğer & 34 & 4,4 & 57,38 & 6,529 & & & & \\
\hline Toplam & 778 & 100 & 59.43 & 6,529 & & & & \\
\hline
\end{tabular}

Tablo 2.5. incelendiğinde $\mathrm{p}$ değeri 0,05 'ten küçük olduğu görülmektedir. $\mathrm{Bu}$ da sınıflar arasında anlamlı bir farklılığın olduğunu göstermektedir [F(6771)=3.584 p<.05]. Bu farklılığın hangi sınıflara arasında olduğunu tespit etmek için çoklu karşılaştırma testlerinden (Post-Hoc) Games-Howell testi uygulanmıştır. Test sonuçlarına bakıldığında anlamlı farkın, okula kendi isteğiyle kayıt yaptıran öğrencilerin OMÖ-ORT puanlarıyla $(\overline{\mathrm{x}}=60,33)$ ailesinin isteğiyle kayıt yaptıran öğrencilerin OMÖ-ORT puanları $(\overline{\mathrm{x}}=58,55)$ arasında olduğu tespit edilmiștir $(\mathrm{p}<.05)$. Bu durum; öğrencilerin okula kayıt nedenleri değişkeninin, öğrencilerin okul motivasyonunda farklılaşma olușturan bir değiş̧ken olarak ele alınabileceğini göstermektedir.

Aşlamacı'nın (2017) yapmış olduğu, ortaokul öğrencilerinin din eğitimi derslerine karşı tutumunu ölçen çalışmasında da kendi isteği ile okulu tercih eden öğrencilerin tutum puanlarının diğer değișkenlere göre yüksek olduğu görülmüş- 
tür. ${ }^{31}$ Erkan (2019) okula kendi isteğiyle kayıt yaptıran öğrencilerin içsel motivasyon düzeylerinin yüksek olduğu sonucuna ulaşmıştır. ${ }^{32} \mathrm{Bu}$ araştırmada da okula kendi isteğiyle kayıt yaptıran öğrencilerin okul motivasyon düzeyleri, diğer nedenlerle okula kayıt yaptıran öğrencilerin okul motivasyon düzeylerinden yüksek olduğu görülmektedir.

Tablo 2.5 incelendiğinde, araștırmaya katılan öğrencilerin 395'inin $(\% 50,8)$ kendi isteğiyle, 190'ının (\%24,4) ailesinin isteğiyle, 9'unun (\%1,2) öğretmeninin tavsiyesiyle, 51'inin $(\% 6,6)$ evine yakın olması sebebiyle, 89'unun $(\% 11,4)$ eğitim seviyesinin iyi olması sebebiyle, 10'unun $(\% 1,3)$ arkadaşlarının bu okula kayıt yaptırması sebebiyle ve 34'ünün $(\% 4,4)$ diğer nedenlerle okula kayıt yaptırdığı görülmektedir.

Erkan (2019) tarafından yapılan araştırmada "imam hatip ortaokuluna kendi isteğimle geldim." cümlesine 312 öğrenci katıldığını, 64 öğrenci katılmadığını ve 24 öğrenci de kararsız olduğunu ifade etmiştir. "İmam hatip ortaokuluna ailemin isteğiyle geldim." cümlesine; 187 öğrenci katıldığını, 166 öğrenci katılmadığını ve 43 öğrenci de kararsız kaldığını belirtmiştir. 400 öğrenci üzerinde yaplan bu çalışma kendi isteğiyle geldiğini belirten öğrencilerin oranın çok yüksek olduğunu görülmüştür. İki sorudan alınan sonuçlar beraber değerlendirildiğinde öğrencilerin büyük çoğunluğu hem ailesinin isteğiyle hem de kendi isteğiyle imam hatip ortaokuluna kayıt yaptırmış oldukları söylenebilir. ${ }^{33} \mathrm{Bu}$ araştırmada da toplamda $585(\% 75,3)$ öğrenci kendi isteğiyle veya ailesinin isteğiyle imam hatip ortaokuluna kayıt yaptırdığı görülmektedir.

Öğrencilerden kendi isteğiyle okula kaydolanların içsel bir motivasyona sahip oldukları düşünüldüğünde olumlu yönde farklılık oluşması beklenen bir durumdur. Öğrencilerin okula kayıt yaptırmadan önce okul hakkında bilgili olması da bu farklılıkta etkili olmuş olabilir. Bu durumda ailenin isteğiyle okula kayıt yaptıran öğrencilerin aleyhine bir farklılığın oluşmasının önüne geçebilmek için ailelerin çocuklarını okul hakkında yeterince bilgilendirmeleri ve çocukta içsel veya dışsal motivasyon oluşturmaları gerektiği söylenebilir.

\section{6. İmam Hatip Ortaokullarında Okuyan Öğrencilerin Önceki Kur'an-ı Ke- rim Okuma Bilgisine Göre OMÖ-ORT Puanlarına İlişkin Bulguların Yorum- lanması}

İmam İmam hatip ortaokullarında okuyan öğrencilerin ortaokul öncesi Kur'an-ı Kerim okuma bilgisine göre OMÖ-ORT puanlarının farklı olup olmadı̆̆ını tespit etmek için bağımsız t-testi analizi sonucunda elde edilen bulgular aşağıda sunulmuştur.

31 İbrahim Așlamacı, Paydaşlarına Göre İmam-Hatip Ortaokullarında Din Eğitimi (İstanbul: Değerler Eğitimi Merkezi Yayınları, 2017).

32 Erkan, Öğrenci Gözüyle Imam Hatip Ortaokullarında Motivasyon Düşüklüğünün Sebepleri: : Karabağlar Örneği.

${ }^{33}$ Erkan, Öğrenci Gözüyle Imam Hatip Ortaokullarında Motivasyon Düşüklüğünün Sebepleri: : Karabağlar Örneği. 
Tablo 2.6. İmam Hatip Ortaokullarında Okuyan Öğrencilerin Önceki Kur'an-ı Kerim Okuma Bilgisine Göre OMÖ-ORT Puanları Arasındaki Farklılık

\begin{tabular}{lccccccccc}
\hline \multirow{2}{*}{ Değişken } & $\begin{array}{l}\text { Önceki Kur'an } \\
\text { Okuma Bilgisi }\end{array}$ & $\mathbf{n}$ & $\mathbf{\%}$ & $\overline{\mathbf{x}}$ & ss & t & sd & p \\
\cline { 1 - 7 } $\begin{array}{l}\text { OMÖ-ORT Toplam } \\
\text { Motivasyon }\end{array}$ & Evet & 688 & 88,4 & 59,50 & 6,528 & \multirow{2}{*}{, 854} & 776 &, 839 \\
\cline { 2 - 7 } & Hayır & 90 & 11,6 & 58,88 & 6,551 & & & \\
\hline
\end{tabular}

Tablo 2.6. incelendiğinde bağımsız örneklem t testi sonuçlarına göre ortaokul öncesi Kur'an-ı Kerim okumayı bilen öğrencilerin OMÖ-ORT puanları $(\bar{x}=59,5)$ ile ortaokul öncesi Kur’an-ı Kerim okumayı bilmeyen öğrencilerin OMÖ-ORT puanları $(\overline{\mathrm{x}}=58,88)$ arasında istatistiksel olarak anlamlı bir farklılık görülmemiştir [t(776)=-.854, p>.05]. Bu durum; önceki Kur'an-ı Kerim okuma bilgisi değişkeninin, öğrencilerin okul motivasyonunda farklılık oluşturan bir değişken olarak ele alınamayacă̆ını göstermektedir.

Öğrencilerin ortaokuldan önceki Kur'an-ı Kerim okuma bilgisi değişkeninin imam hatip ortaokulu öğrencilerinin okul motivasyonlarında farklılaşma oluşturacağı düşüncesiyle sorulan bu soruyla ilgili alanyazında herhangi bir çalışmaya rastlanmamıştır. Kur'an-ı Kerim okuma bilgisi değişkeninin farklılık oluşturmamasında, öğrencilerin çoğunun Kur'an-ı Kerim okumayı bilerek okula gelmesinin etkili olduğu söylenebilir. Din eğitiminde önemli bir yer tutan Kur'an-ı Kerim okuma bilgisine sahip olmak, öğrencilerin din eğitimi verilen okula alışmaları ve zorlanmamaları açısından önemlidir.

\section{7. İmam Hatip Ortaokullarında Okuyan Öğrencilerin İmam Hatip Lisesine Devam İsteğine Göre OMÖ-ORT Puanlarına İlişkin Bulguların Yorumlanma- S1}

İmam hatip ortaokullarında okuyan öğrencilerin imam hatip lisesine devam isteğine göre OMÖ-ORT puanlarına bakılmış ve bu puanlar arasında istatistiksel olarak anlamlı bir farkın olup olmadığını tespit etmek için Tek Yönlü Varyans Analizi (ANOVA) uygulanmıştır. İstatistiksel olarak anlamlı bir farklılık tespit edilmiş ve (Post-Hoc) Games-Howell testi uygulanmıştır. Testlerle ilgili bulgular aşağıdaki tabloda sunulmuştur.

Tablo 2.7. İmam Hatip Ortaokullarında Okuyan Öğrencilerin İmam Hatip Lisesine Devam İsteğine Göre OMÖ-ORT Puanları Arasındaki Farklılığa İlişkin Yapılan Tek Yönlü Varyans Analizi (ANOVA) Sonuçları

\begin{tabular}{lcccccccc}
\hline \multicolumn{1}{c}{ Değişken } & $\mathbf{n}$ & $\mathbf{\%}$ & $\overline{\mathbf{x}}$ & $\mathbf{s s}$ & $\mathbf{s d}$ & $\mathbf{F}$ & $\mathbf{p}$ & $\begin{array}{c}\text { Anlaml } \\
\text { Fark }\end{array}$ \\
\hline Evet & 265 & 34,1 & 60,63 & 6,081 & $2 / 775$ & 7,569 &, 00 & \\
Hayır & 265 & 34,1 & 59,14 & 6,881 & & & & $1-2$ \\
$\begin{array}{l}\text { Başka bir okulu kaza- } \\
\text { namazsam evet }\end{array}$ & 248 & 31,9 & 58,46 & 6,435 & & & & $1-3$ \\
Toplam & 778 & 100 & 59.43 & 6,529 & & & & \\
\hline
\end{tabular}

Tablo 2.7. incelendiğinde $\mathrm{p}$ değeri 0,05 'ten küçük olduğu görülmektedir. Bu 
da öğrencilerin imam hatip lisesine devam istekleri arasında istatistiksel olarak anlamlı bir farklılığın olduğunu göstermektedir $[\mathrm{F}(2-775)=7.569 \mathrm{p}<.05]$. Bu farklılığın hangi istekler arasında olduğunu tespit etmek için çoklu karşılaştırma testlerinden (Post-Hoc) Games-Howell testi uygulanmıştır. Test sonuçlarına bakıldığında anlamlı farkın, "evet" ( $\bar{x}=60,63)$ cevabı verenlerle "hayır" ( $\bar{x}=59,14)$ cevabı verenler ve "evet" ( $\overline{\mathrm{x}}=60,63)$ cevabı verenlerle "başka bir okulu kazanamazsam evet" $(\bar{x}=58,46)$ cevabı verenler arasında olduğu tespit edilmiştir. Farklılığın yönünü tespit etmek için sınıfların OMÖ-ORT puanlarına bakıldığında farklılığın imam hatip lisesine devam etmek isteyen öğrencilerin lehine olduğu görülmüștür. $\mathrm{Bu} \mathrm{du-}$ rum; imam hatip lisesine devam etmek isteği değişkeninin, öğrencilerin okul motivasyonunda farklılık oluşturan bir değişken olarak ele alınabileceğini göstermektedir.

Erkan (2019) tarafından yapılan çalışmaya bakıldığında, öğrencilerin okudukları ortaokuldan memnun olmalarına rağmen öğrencilerin yarıdan fazlasının imam hatip lisesine devam etmek istemedikleri görülmüștür. ${ }^{34}$ Bu çalışmada öğrencilerden imam hatip lisesine devam etme isteğinde olanların okul motivasyon düzeyleri görece devam etmek istemeyenlerden ve başka bir okulu önceleyen öğrencilerden yüksek çıkmıştır. Bu farklılaşmanın oluşmasında öğrencilerin gelecekten beklentilerinin ve okula gelme amaçlarının etkili olduğu söylenebilir.

Tablo 2.7'ye bakıldığında, araştırmaya katılan öğrencilerin 265'inin (\%34,1) imam hatip lisesine devam etmeyi düşündüğü, 265'inin $(\% 34,1)$ İmam Hatip Lisesine devam etmeyi düșünmediği, 248'inin $(\% 31,9)$ ise ilk tercihi İmam Hatip Lisesi olmasa da başka bir okulu kazanamadığı takdirde İmam Hatip Lisesine devam etmeyi düşündügü görülmektedir.

Erkan (2019) tarafından yapılan araştırmada "liseye imam hatip lisesine gitmek isterim" cümlesine; 105 öğrenci katıldığını, 205 öğrenci katılmadığını ve 89 öğrenci de kararsız olduğunu belirtmiştir. Bu sonuçlara bakıldığında öğrencilerin yarısının imam hatip lisesine devam etmeyi düşünmediği görülmüștür. ${ }^{35}$ Fakat bu araştırmada öğrencilerin üçte biri imam hatip lisesine devam etmeye isteklidir. Diğer üçte biri ise başka bir okul kazanamadığı durumda imam hatip lisesine devam etmeyi düşünmektedir. Geriye kalan üçte biri ise imam hatip lisesine devam etmek istememektedir. İmam hatip lisesine devam etmek istemeyen öğrencilerin, isteksizliklerinin nedenleri üzerine çalışmalar yapılması gerekmektedir.

\section{Sonuç}

$\mathrm{Bu}$ araștırmada imam hatip ortaokulu öğrencilerinin okul motivasyonu düzeyleri çeşitli değişkenler açısından incelenmiştir. Araştırma sonucunda elde edilen bulgular analiz edildiğinde; beklentinin aksine, anne ve baba eğitim durumu, imam hatip ortaokulu öncesi Kur'an-ı Kerim okumayı bilme durumu, imam hatip

\footnotetext{
${ }^{34}$ Erkan, Öğrenci Gözüyle Imam Hatip Ortaokullarında Motivasyon Düşüklüğünün Sebepleri: : Karabağlar Örneği.

${ }^{35}$ Erkan, Öğrenci Gözüyle Imam Hatip Ortaokullarında Motivasyon Düşüklüğünün Sebepleri: : Karabağlar Örneği.
} 
ortaokulu öğrencilerinin okul motivasyonu düzeylerinde farklılık oluşturmadığı görülmüştür. Öğrencilerin cinsiyetleri, bulundukları sınıf düzeyi, okula kayıt nedenleri ve imam hatip lisesine devam etme isteği ile okul motivasyonu düzeyleri arasında anlamlı farklılık tespit edilmiștir.

Araştırmada, katılımcı öğrencilerin cinsiyetlerinin, okul motivasyonu üzerinde, kız öğrenciler lehine bir farklılaşma tespit edilmiştir. Alanyazında Erkan (2019) tarafından gerçekleștirilen çalışmada motivasyon ve cinsiyet arasında farklılaşma tespit edilmemiş olsa da bu çalıșmada bir farklılık oluşturduğu görülmektedir. Bu farklılığın oluşmasının nedenlerini anlamlandırabilmek için cinsiyet farklılıkları ile ilgili alanyazına ${ }^{36}$ bakıldığında; toplumlar arası kültürel farklılıklar göz ardı edildiğinde dahi cinsiyetler arası hormonal ve biyolojik yapının farklı olduğu birçok araştırma tarafından ortaya konulmuş olduğu görülmektedir. Hormonal ve biyolojik farklılıklara bakıldığında da kız çocuklarının erkek çocuklarına göre daha erken ergenliğini tamamladıkları bilinmektedir. Fakat, tek başına hormonal ve biyolojik farklılığın motivasyon üzerinde farklılık olușturduğu söylenemez. Çocuklar, içerisinde yaşadıkları toplumun kültürel özelliklerini ve cinsiyetlere biçilen rolleri, informal eğitim yoluyla öğrenirler ve kendi cinsiyetlerine uygun rolleri benimserler. Toplumumuzda geçerliliğini koruyan geleneksel aile yaşamı erkek ve kız çocuklarına farklı roller sunmaktadır. Bu araştırmada da öğrencilerin, hormonal ve biyolojik farklılıklarının yanında informal bir şekilde gerçekleşen sosyal öğrenmelerin etkili olmuş olabileceği söylenebilir. Örneğin, kız çocuklarının aileden öğrendiği tesettür gibi hem geleneksel hem de dini inaca dayanan tercihleri, imam hatip ortaokuluna dair okul motivasyonları üzerinde etkili olmuş olabilir. Bu konuda daha fazla çalışma yapılması gerekmektedir.

Katılımcı öğrencilerin okudukları sınıfların, okul motivasyonu düzeylerinde farklılaşma oluşturduğu tespit edilmiştir. Beşinci sınıftaki öğrencilerin okul motivasyonları üst sınıflardaki öğrencilerin okul motivasyonlarından oldukça yüksek çıktığı görülmektedir. Bu farklılığın oluşmasında, öğrencilerin okulda beklediklerini bulamamalarından oluşmuş olabileceği gibi ders konularının sınıflar ilerdekçe daha zor ve karmaşık hale gelmesi de bu farklılıkta rol oynamış olabileceği söylenebilir. Öğrencilerin, derslerde yaşadıkları zorluğu ve karmaşıklığı aşamamalarında ve motivasyon kaybına uğramalarında, öğretmenlerin yanlıș tutumları, kullanılan materyallerin uygun olmaması veya eğitim programının öğrencilere göre hazırlanmamış olması gibi birçok farklı değișken etkili olmuş olabilir. Hangi değișkenlerin sınıflar ilerledikçe motivasyonda olumsuz farklılaşmaya neden olduğunun tespiti için daha fazla araştırma yapılması gerekmektedir.

Araștırmada anne eğitim durumu, öğrencilerin okul motivasyonları üzerinde anlamlı bir farklılık oluşturmamaktadır.Alanyazına bakıldığında, anne eğitim durumunun motivasyon düzeyini farklılaştırdığını tespit eden çalışma sayısı, farklılaşma tespit etmeyen çalışmalara oranla oldukça azdır. Araştırmaya başlarken anne eğitim durumunun, öğrencilerin okul motivasyonu düzeylerinde farklılaşma

\footnotetext{
${ }^{36}$ Çakir - Baş, "Cinsiyetler ve Cinsiyetlerle Özdeşleşen Davranışların Sosyolojik ve Biyolojik Açıdan Değerlendirilmesi".
} 
oluşturacağı düşünülmüştür. Fakat elde edilen bulgular farklılaşmanın olmadığını göstermektedir. Araştırmada, katılımcı öğrencilerin baba eğitim durumlarının da öğrencilerin okul motivasyonunda farklılaşmaya neden olmadığı tespit edilmiştir. Ebeveyn eğitim durumu ve okul motivasyonu ile ilgili daha fazla araştırma yapılması gerekmektedir.

Ebeveyn eğitim düzeyi ve akademik başarı üzerine yapılan çalışmalara bakıldığında genel itibariyle matematik, fen ve Türkçe alanlarının merkeze alındığ görülmektedir. Ebeveynin matematik ve fen alanlarında eğitimli olması elbette çocuğun bu alanlardaki akademik başarısına olumlu yansıyacaktır. Evinde küçük de olsa bir kütüphaneye sahip olan ebeveynlerin çocukları okuma üzerine olumlu etkilenecekler ve bu da Türkçe dersinde başarıyı arttırabilecektir. Bütün bunlardan yola çıkarsak, din eğitimi almış ve öğrendiği dini bilgileri evinde yaşayan ebeveynlerin çocukları da din eğitiminde başarılı olabilecekleri söylenebilir. Bu düşünceden yola çıkıldığında bu öğrencilerin okul motivasyonlarının farklılaşacağı beklenebilir. Bu alanda daha çok çalışma yapılması ve net sonuçlar ortaya konması gerekmektedir.

$\mathrm{Bu}$ araştırmada toplamda $585(\% 75,3)$ öğrencinin kendi isteğiyle veya ailesinin isteğiyle imam hatip ortaokuluna kayıt yaptırdığı görülmektedir. İlgili alanyazınla karşılaştırıldığında benzer sonuçlar olduğu ve öğrencilerin yarıdan fazlasının kendi isteğiyle veya ailesinin isteğiyle okula kayıt yaptırdığı görülmüştür. İmam hatip ortaokullarında okuyan öğrencilerin okula kayıt nedenlerine bakıldığında; kendi isteğiyle kayıt yaptıran öğrencilerin okul motivasyonu düzeyleri ile ailesinin isteğiyle kayıt yaptıranların okul motivasyonu düzeyleri arasında anlamlı farklılaşma görülmektedir. Kendi isteğiyle kayıt yaptıran öğrencilerin okul motivasyonu düzeyleri, ailelerinin isteğiyle kayıt yaptıranların okul motivasyonu düzeylerinden yüksek olduğu tespit edilmiştir. Bir öğrencinin okula kendi isteğiyle gelmesi okul motivasyonunu artırmaktadır. İçsel motivasyonun bu farklılaşmada etkili olduğu söylenebilir.

Araştırmanın başında, ilkokul müfredatında olmayan ve örgün eğitim içerisinde ilk defa program içerisinde verilen Kur'an-ı Kerim dersiyle ilgili olarak; ortaokul öncesi Kur'an-ı Kerim okuma bilgisine sahip olan öğrencilerin, hazır bulunuş itibariyle Kur'an-ı Kerim okuma bilgisine sahip olmayan öğrencilere kıyasla daha iyi bir konumda olacakları düşüncesiyle okul motivasyonlarının yüksek olması beklenmiştir. Fakat sonuçlar farklılığın olmadığını göstermiştir. Farklılığın oluşmamasında öğrencilerin çoğunluğunun $(\% 88,4)$, okula Kur'an-ı Kerim okumayı bilerek gelmiș olması etkili olmuş olabilir.

Araștırmada yapılan analiz sonucunda, araştırmaya katılan imam hatip ortaokulu öğrencilerinin, imam hatip lisesine devam etme isteğinde olanlarla devam etmek istemeyen ve başka bir liseyi öncelikli olarak düşünen öğrencilerin okul motivasyonu düzeylerinin farklılaştığı görülmektedir. İmam hatip lisesine devam etmek isteyen öğrencilerin okul motivasyonları, devam etmek istemeyen veya başka bir liseyi öncelikli olarak düşünenlerin okul motivasyonlarına göre yüksek çıkmıştır. Bu sonuç, öğrencinin okuduğu okulun, gelecekten beklentilerine ve hedeflerine uygun olmasının, okul motivasyonunu arttırdığını göstermektedir. İlgili alanyazına bakıldığında, öğrencilerin okudukları ortaokuldan memnun olmalarına rağmen 
öğrencilerin yarıdan fazlasının imam hatip lisesine devam etmek istemedikleri görülmüştür. Öğrencilerin bu isteksizliklerinin nedenlerinin tespit edilmesi için çalışmalar yapılması gerekmektedir. Bu çalışmaların din eğitimi alanyazını açısından önemli bir boşluğu dolduracağı düşünülmektedir.

Araştırmanın sonuçlarından yola çıkarak şu önerilerde bulunulmaktadır:

Ortaokula yeni başlayan öğrencilerin okula karşı yüksek olan motivasyonları, ilerleyen yıllarda da yüksek tutulmaya çalışılmalı ve öğrencileri motive edici faaliyetler geliştirilmelidir.

Öğrencilerin okula kendi istekleriyle kayıt yaptırmaları için okulların tanıtımı yapılmalı ve öğrenciler okul hakkında bilgilendirilmelidir.

Author Contributions / Yazarların Katkısı: This article is a work with twoauthors. The contribution of the aforementioned authors to the preparation of the article is sixty percent and fourty percent, respectively. / Bu makale, iki yazarlı bir çalışmadır. Makalenin hazırlanmasına söz konusu yazarların katkısı sırasıyla, \%60 ve $\% 40$ şeklindedir.

Funding / Finansman: This research received no external funding. / Bu araștırma herhangi bir dış fon almamıștır.

Conflicts of Interest / Çıkar Çatışması: The authors declare no conflict of interest. / Yazarlar, herhangi bir çıkar çatışması olmadığını beyan eder.

\section{Kaynakça}

Așlamacı, İbrahim. Paydaşarına Göre İmam-Hatip Ortaokullarında Din Eğitimi. İstanbul: Dem Yayınları, 2017.

Așlamacı, İbrahim. "Türkiye'nin İslam Eğitim Modeli: İmam-Hatip Okulları ve Temel Özellikleri". Journal of Turkish Studies 9/ (2014), 49-80. https://doi.org/10.7827/TurkishStudies.6908

Bahtiyar, Asiye - Can, Bilge. "Ortaokul (5., 6., 7., ve 8. Sınıf) Öğrencilerinin Daimî Bilim Öğrenme Motivasyonlarının Íncelenmesi". Pamukkale Üniversitesi Eğitim Fakültesi Dergisi 41/41 (01 Ocak 2017), 121-129.

Bilgin, Beyza - Selçuk, Mualla. Din Öğretimi ve Özel Öğretim Yöntemleri. Ankara: Gün Yayıncilık, 1999.

Bloom, Benjamin Samuel. Insan Nitelikleri ve Okulda Öğrenme. çev. Durmuş Ali Özçelik. Ankara: Pegem Akademi, 2016.

Çakir, Hülya - Baş, Hatice. "Cinsiyetler ve Cinsiyetlerle Özdeşleşen Davranışların Sosyolojik ve Biyolojik Açıdan Değerlendirilmesi”, 176-191.

Erkan, Durmuș. Öğrenci Gözüyle İmam Hatip Ortaokullarında Motivasyon Düşüklüğünün Sebepleri: Karabağlar Örneği. İzmir: Dokuz Eylül Üniversitesi, Yüksek Lisans Tezi, 2019.

https://tez.yok.gov.tr/UlusalTezMerkezi/TezGoster?key=npGs9H39x7G6401x51yq pFa9NryfUQrmk_F4h4slNaMTScThsv1K-G3duGH809eS

Fidell, Linda S. - Tabachnick, Barbara. Çok Değișkenli İstatistiklerin Kullanımı. çev. Mustafa Baloğlu. İstanbul: Nobel Akademik Yayıncılık, 2015.

Karasar, Niyazi. Bilimsel Araştırma Yöntemi: Kavramlar Illkeler Teknikler. Ankara: Nobel, 2018.

Karasu, Tecelli. “Imam Hatip Meslek ve Dikap Dersi Öğretmenlerinin Eğitim Bilişsim Ağı (EBA) ile İlgili Görüşleri". Bitlis Eren Üniversitesi Sosyal Bilimler Dergisi 7/2 (21 Aralık 2018), 925-943. 
Kaynak, Semih vd. "Ortaokul Öğrencileri İçin Okul Motivasyonu Ölçeği Geliştirme Çalışması". Journal of Turkish Studies 12/ (01 Ocak 2017), 293-312. https://doi.org/10.7827/TurkishStudies.11336

Kayri, Murat. "Araştırmalarda Gruplar Arası Farkın Belirlenmesine Yönelik Çoklu Karşılaştırma (Post-Hoc) Teknikleri". Fırat Üniversitesi Sosyal Bilimler Dergisi 19/1 (2009), 51-64.

Krejcie, Robert V. - Morgan, Daryle W. "Determining Sample Size for Research Activities". Educational and Psychological Measurement 30/3 (Eylül 1970), 607-610. https://doi.org/10.1177/001316447003000308

Midgley, Carol. Motivation and Middle Level Schools. Greenwich: CT:JAI Press, 1993.

Selçuk, Ziya. Gelişim ve Öğrenme. Ankara: Nobel Yayın Dağıtım, 2001.

Selçuk, Ziya - Güner, Nedret. Sınıf İçi Rehberlik Uygulamaları. Ankara: Pegem Yayıncılık, 2003.

Stipek, Deborah J. Motivation To Learn: From Theory To Practice. Boston - US: Allyn ve Bacon, 1998.

Şimşek, Eyüp. İlköğretim Din Kültürü ve Ahlak Bilgisi Dersi Öğretmenlerinin Yeterlikleri (Erzurum Örneği). Erzurum: Atatürk Üniversitesi, Doktora Tezi, 2006. https://tez.yok.gov.tr/UlusalTezMerkezi/TezGoster?key=XohQ0H2mJnBfxLPsY8dG 4zRI-PUZeB85K4ncWJEeu5a784QEtANjfU-d7fIDB-Px

Şişman, Mehmet. Eğitim Bilimine Giriş. Pegem Akademi, 2008.

Viau, Rolland. Okulda Motivasyon Okulda Güdüleme ve Güdülenmeyi Öğrenme. çev. Yusuf Budak. Ankara: Anı Yayıncılık, 2015.

Wheaton, Blair vd. "Assessing Reliability and Stability in Panel Models". Sociological Methodology 8/ (1977), 84-136. https://doi.org/10.2307/270754

Woolfolk, Anita. Eğitim Psikolojisi. çev. Duygu Özen. İstanbul: Kaknüs Yayınları, 2015.

YerliKaya, İbrahim. "İlkokul ve Ortaokul Öğrencilerinin Eğitime İlişkin Motivasyonlarının Çeșitli Değișkenler Açısından İncelenmesi". Journal Of History School 7/XIX (01 Ocak 2014), 773-795. https://doi.org/10.14225/Joh602

Yeung, Alexander Seeshing - McInerney, Dennis M. "Students' School Motivation and Aspiration Over High School Years". Educational Psychology 25/5 (01 Ekim 2005), 537-554. https://doi.org/10.1080/01443410500046804

Yüksel, Galip. "Öğrenme İçin Motivasyon”. Sinıf Yönetimi. ed. M. Çağatay Özdemir. Ankara: Pegem Akademi, 2017. 